\title{
Copepods as microbial hotspots in the ocean: effects of host feeding activities on attached bacteria
}

\author{
Kam W. Tang* \\ Virginia Institute of Marine Science, PO Box 1346, 1208 Greate Road, Gloucester Point, Virginia 23062, USA
}

\begin{abstract}
Through ingestion a copepod introduces rich organic substrates into its guts and fecal pellets, where dense bacteria may exploit them and show fast growth. Thus, a copepod and its fecal pellets may be regarded as microbial hotspots in the ocean. This study investigated the effects of copepods' feeding activities on the associated bacteria, using the Most Probable Number (MPN) method. Starved Acartia tonsa (calanoid copepod) carried a background bacteria population of $10^{3}$ to $10^{4}$ copepod $^{-1}$. When fed axenic cultures of algae Rhodomonas salina or Dunaliella tertiolecta, the bacterial abundance increased curvilinearly with the copepods' ingestion rates. When fed axenic cultures of diatom Thalassiosira weissflogii, the bacterial abundance showed a hump-shaped response to the ingestion rate. These observations support a conceptual model of a balance between bacteria growth stimulated by the host's feeding and bacteria loss through the host's defecation. The equivalent bacterial population density associated with the copepods was orders of magnitude higher than typical population density of marine free-living bacteria. In a time series experiment, bacteria inside the copepods' bodies increased significantly after $3 \mathrm{~d}$ of feeding, and the estimated bacterial growth rate was $0.89 \mathrm{~d}^{-1}$, higher than the average growth rate for free-living pelagic bacteria. The copepods released a significant amount of bacteria via defecation when food was present, and the equivalent bacterial abundance associated with fecal pellets was $6.5 \times 10^{8}$ bacteria ml $^{-1}$. Bacteria recovered from $A$. tonsa feeding on different diets showed different growth kinetics in enrichment cultures, suggesting that diet types may be a selective force for different bacterial communities inside the host's body.
\end{abstract}

KEY WORDS: Acartia tonsa $\cdot$ Microbial hotspot $\cdot$ Bacteria $\cdot$ Colonization $\cdot$ Most Probable Number Fecal pellets Resale or republication not permitted without written consent of the publisher

\section{INTRODUCTION}

The marine water column is usually regarded as a nutritionally dilute environment and the growth of free-living bacteria is limited by available organic substrates (Kirchman \& Rich 1997, Church et al. 2000, Pomeroy \& Wiebe 2001). The presence of various types of particles, such as detritus and marine snow, creates locally elevated concentrations of organic substrates, representing favorable microhabitats for bacteria (Alldredge \& Silver 1988, Smith et al. 1992, Simon et al. 2002, Turner 2002). Marine detritus and marine snow are often heavily colonized by bacteria, at population densities many orders of magnitude higher than free- living bacteria (Alldredge et al. 1986, Turley \& Mackie 1994, Ploug et al. 1999). However, research in marine microbial ecology is traditionally biased toward freeliving bacteria, and the ecological significance of microhabitats for pelagic bacteria has not been fully explored.

Marine copepods also have complex body structures and extensive surfaces for bacterial attachment. Through feeding activities copepods collect and concentrate food particles into their guts; some of the ingested food will be eventually released as fecal pellets. Thus, like detritus and marine snow, copepod guts and fecal pellets also represent highly concentrated sources of organic substrates relative to the 
ambient water. The exterior of a copepod body also provides surfaces for bacterial attachment. Yet, unlike detritus and marine snow, a copepod can continuously collect organic food into its guts and produce fecal pellets; hence, a copepod can be regarded as a 'microbial hotspot' that allows continuous production and release of bacteria into the water column. Appearance of dense bacteria in copepod exterior, guts, and fecal pellets have been observed for decades (Honjo \& Roman 1978, Turner 1979, Nagasawa et al. 1985, Nagasawa \& Nemoto 1988, Carman 1994, Delille \& Razouls 1994, Hansen \& Bech 1996, Carman \& Dobbs 1997), yet most of these studies tend to be descriptive and little is known of the interactions between the bacteria and their hosts. Because bacteria residing in these microhabitats rely on the host to supply organic substrates through feeding activities, the objective of this study is to investigate how the feeding activities of host copepods affect the attached bacteria in their bodies and fecal pellets.

\section{MATERIALS AND METHODS}

Axenic phytoplankton cultures. Axenic phytoplankton cultures were obtained from CCMP (Center for Culture of Marine Phytoplankton), Maine. Three species were used in this study: Rhodomonas salina (CCMP1319; cryptophyte), Dunaliella tertiolecta (CCMP1320; chlorophyte), and Thalassiosira weissflogii (CCMP1336; diatom). Microscopic examinations of DAPI-stained seed stocks confirmed the absence of bacteria. All cultures were grown under axenic conditions in $\mathrm{f} / 2$ or $\mathrm{f} / 2+\mathrm{Si}$ medium at $20^{\circ} \mathrm{C}$ with a light:dark cycle of $12: 12 \mathrm{~h}$. Culture medium was made with sterilized $20 \% 0.2 \mu \mathrm{m}$ filtered Instant Ocean artificial seawater (ASW). All cultures were handled inside a biosafety cabinet with filtered laminar airflow to avoid bacterial contamination. The cultures were checked for bacterial contamination a few days prior to each experiment: aliquots of the cultures were used to inoculate marine mineral-marine broth (MM-MB) medium (see 'MM-MB medium') and the inocula were subsequently incubated at $25^{\circ} \mathrm{C}$ in the dark. Development of cloudiness in the medium would indicate bacterial contamination; in such cases the cultures would not be used for experiments. The same criterion was used in the Most Probable Number (MPN) inoculation to quantify bacteria in the subsequent experiments (see 'Bacterial abundance by the MPN method').

Copepod cultures. The common calanoid copepod Acartia tonsa was collected from the York River, Virginia, USA, and maintained in cultures at $20^{\circ} \mathrm{C}$ in the laboratory. The copepods were fed a mixture of Rhodomonas salina and Thalassiosira weissflogii regularly. New offspring were periodically collected and trans- ferred to new containers. The condition of the cultures was checked regularly and the water changed when necessary. Only healthy female Acartia tonsa were used for experiments.

Bacterial abundance by the MPN method. Bacteria in copepods and fecal pellets were quantified by the MPN method as described in Tang et al. (2001) with slight modification. Copepods and fecal pellets collected from the experiments were homogenized in sterile vials (see 'Feeding experiments', 'Time-series experiments' and 'Defecation experiments'). The homogenate was then serially diluted with sterile seawater to a concentration of $10^{\circ}$ (most concentrated) to $10^{-8}$ (most diluted). Aliquots from each dilution level were used to inoculate MM-MB medium (see 'MM-MB medium') in triplicate sterile test tubes. Inoculation was done inside a biosafety cabinet to prevent contamination. All tubes were loosely capped to allow gaseous exchange, and were incubated in the dark at $25^{\circ} \mathrm{C}$. The tubes were gently agitated on a vortex after $10 \mathrm{~d}$ to replenish dissolved oxygen. This incubation method did not differentiate among aerobic bacteria, facultative anaerobes and obligatory anaerobes (see 'Discussion'). At the end of $20 \mathrm{~d}$, the tubes were visually examined for bacteria growth as indicated by cloudiness of the medium. Depending on the frequency of positive bacteria growth in each dilution series, the most probable number of bacteria in the original homogenate was determined according to DeMan (1975). Because the MPN method quantified actively growing bacteria rather than the total bacteria (which include inactive or dormant bacteria), the bacterial abundance estimated this way likely reflected the active fraction of the total bacteria associated with the copepods and fecal pellets (cf. Hansen \& Bech 1996). A preliminary test showed that MPN tubes that showed negative growth contained a small number of bacteria weakly visible after staining with DAPI, probably indicating the presence of non-viable or non-culturable bacteria.

MM-MB medium. MM medium was prepared according to Hines et al. (1997), which contained various mineral compounds required by most marine bacteria. The MM medium contained carbonate as $\mathrm{pH}$ buffer and was adjusted to a $\mathrm{pH}$ of 7 . MB solution $\left(15 \mathrm{~g}^{-1}\right.$; $\mathrm{pH}$ 7) was prepared with Difco Marine Broth powder, which contained a broad variety of organic substrates commonly used for growing marine bacteria. MM-MB medium was prepared by mixing $\mathrm{MM}$ medium and $\mathrm{MB}$ solution in a 1:1 ratio; the mixture thus provided both organic and inorganic nutrients required for bacterial growth.

Feeding experiments. Feeding experiments were conducted to test the hypothesis that bacterial content of a copepod is a function of the copepod's feeding rate. Female Acartia tonsa were starved in particle- 
free ASW overnight to minimize the interference due to feeding history. The copepods were then acclimated to the experimental food solutions for $24 \mathrm{~h}$ prior to the start of the experiments. The food solutions were prepared by mixing stock phytoplankton cultures with sterile $\mathrm{f} / 2$ or $\mathrm{f} / 2+\mathrm{Si}$ (for diatom) to the desired food concentrations. A range of food concentrations was used to obtain different ingestion rates. All food concentrations were tested with 10 copepods per bottle $(129 \mathrm{ml})$. Duplicate bottles without copepods were used as controls. All bottles were secured to a rotating wheel $(0.25 \mathrm{rpm})$ to maintain the food in suspension. All experiments were done at $20^{\circ} \mathrm{C}$ with a light:dark cycle of 12:12 h. Aliquots of the food solutions were preserved in Lugol's solution at the start and the end of the experiments for quantifying food concentrations. The copepods were recovered at the end of the experiments on a $200 \mu \mathrm{m}$ sieve and examined under a stereomicroscope. Ingestion rate of the copepods for each bottle was calculated based on the cell count data following the equations of Frost (1972), and related to the corresponding MPN for that bottle. The recovered copepods were rinsed at least 3 times in sterile ASW to remove loosely attached bacteria on the copepod body surfaces. The rinsed copepods were blot-dried on sterile GF/F glass fiber filters, and transferred to sterile plastic test tubes with $2 \mathrm{ml}$ of sterile ASW in an ice bath. The copepods were then homogenized with an ultrasonic homogenizer (4 W output; 5 cycles of $5 \mathrm{~s}$ on/5 s off). A preliminary test showed that this procedure successfully homogenized copepod tissues with no visible remains. Hansen \& Bech (1996) used a homogenizer with a higher power output than this study and observed no loss of bacteria. At the end of the homogenization cycle, the probe was rinsed with $1 \mathrm{ml} \mathrm{ASW}$ into the test tubes so that the final homogenate volume was $3 \mathrm{ml}$. All working surfaces were cleaned with $70 \% \quad 0.2 \mu \mathrm{m}$ filtered isopropyl ethanol between samples. The homogenate was then used for MPN inoculation as described earlier. While the MPN inoculation was done inside a biosafety cabinet, the sorting and homogenizing of copepods had to be done in open space with the risk of bacterial contamination from air. Therefore, a preliminary test was conducted to test if contamination would be a problem during these procedures. An aliquot of ASW was processed in the same manner as the copepods were treated and used for MPN inoculation. No bacterial growth was observed in this preliminary test, suggesting negligible contamination by the experimental procedures.

Time-series experiment. An experiment was conducted to test if the bacterial contents of copepods increased with the duration of their feeding activities. A batch of 200 Acartia tonsa were starved in ASW for about $12 \mathrm{~h}$ to minimize the interference of their feeding history. At the end of the starvation periods (Day 0), randomly selected live copepods were used for bacterial extraction and MPN inoculation ( 7 copepods per extraction; triplicate). Remaining copepods were transferred to incubation bottles with a nominal concentration of $10^{4} \mathrm{ml}^{-1}$ of an axenic culture of Thalassiosira weissflogii (CCMP1336). After $1 \mathrm{~d}$ of feeding, randomly selected live copepods were used for bacteria extraction and MPN inoculation $(7$ copepods per extraction; triplicate). Remaining copepods were transferred to new bottles with freshly prepared solution of $10^{4} \mathrm{ml}^{-1}$ of an axenic culture of T. weissflogii. At the end of Day 3, the live copepods were collected and used for bacteria extraction and MPN inoculation ( 7 to 9 copepods per extraction; triplicate).

Defecation experiment. An experiment was conducted to test the hypothesis that copepods release bacteria to the surrounding water via defecation. Copepods were acclimated for $24 \mathrm{~h}$ to 1 of the 2 treatments: Starvation treatment $=\mathrm{ASW}$; Food treatment $=$ $3 \times 10^{4}$ cells ml ${ }^{-1}$ of an axenic culture of Thalassiosira weissflogii (CCMP1336). After acclimation, live copepods in each treatment were transferred to incubation bottles $(129 \mathrm{ml})$ with either ASW (10 copepods bottle ${ }^{-1}$; triplicate) or $3 \times 10^{4}$ cells ml ${ }^{-1}$ of $T$. weissflogii (8 to 9 copepods bottle ${ }^{-1}$; triplicate). Triplicate bottles with only $3 \times 10^{4}$ cells $\mathrm{ml}^{-1}$ of $T$. weissflogii were used as controls. After $6 \mathrm{~h}$ of incubation, the contents of each bottle were first passed through a $200 \mu \mathrm{m}$ sieve to collect the copepods, which were examined under a stereomicroscope for survival; the remaining bottle contents were then passed through a $20 \mu \mathrm{m}$ sieve to collect the fecal pellets. The sieves that came into contact with copepods and fecal pellets were cleaned with $70 \% 0.2 \mu \mathrm{m}$ filtered isopropyl alcohol prior to use. Some eggs were also observed, but they were not abundant. Some diatoms were also collected. Since axenic cultures of diatoms were used for the experiment, they did not contribute bacteria to the samples. The collected material was transferred to sterile petri dishes and the fecal pellets enumerated, after which the material in each petri dish (fecal pellets, eggs and diatoms) was transferred to a sterile filtration funnel and concentrated onto a sterile GF/F glass fiber filter under a suction pressure of $<10 \mathrm{kPa}$. Afterward the filter was transferred to a sterile centrifuge tube and $5 \mathrm{ml} \mathrm{ASW}$ was added. Bacteria collected on the filter were extracted using an ultrasonic homogenizer (see 'Feeding experiments'). To separate the bacteria from the remaining filter debris, the tube was centrifuged at $2000 \mathrm{rpm}(7.1 \times \mathrm{g})$ for $5 \mathrm{~min}$ at $4^{\circ} \mathrm{C}$, and only the supernatant was used for MPN inoculation. Diatoms were recovered from the control bottles by sieving as evident by a slight brown color of the filter. The controls were processed in the same manner as the experimen- 
tal bottles and would allow for correction for bacteria introduced by contamination.

Bacterial growth experiment. An experiment was conducted to test the hypothesis that copepods feeding on different diets favor different types of bacteria as indicated by different growth kinetics of bacteria recovered from the copepod bodies. A batch of 45 Acartia tonsa were first starved in ASW overnight; randomly selected live copepods were then incubated with each of the 3 algal species (10 copepods per $315 \mathrm{ml}$ bottle; food concentration $=3 \times 10^{4}$ cells $\mathrm{ml}^{-1}$ ). After $48 \mathrm{~h}$ of incubation, 5 copepods were collected from each food treatment for bacterial extraction and MPN inoculation. After $20 \mathrm{~d}$, bacteria recovered from the highest dilution level with positive growth in each MPN series (representing numerically dominant strains) were used to establish enrichment cultures with MM-MB medium in $100 \mathrm{ml}$ Erlenmeyer flasks. After $5 \mathrm{~d}$ the enrichment cultures grew to high densities and were used to study growth kinetics: $0.1 \mathrm{ml}$ aliquot was transferred from each enrichment culture to Erlenmeyer flasks (in triplicate) with $100 \mathrm{ml} \mathrm{MM-}$ $\mathrm{MB}$ medium. All flasks were incubated under aerobic conditions at $25^{\circ} \mathrm{C}$ in the dark. Aliquots from each flask were taken for optical density (OD) measurements at $580 \mathrm{~nm}$ periodically to assess bacterial growth.

\section{RESULTS}

\section{Feeding experiments}

Eight feeding experiments were conducted using axenic cultures of 3 algal species: Rhodomonas salina (CCMP1319), Thalassiosira weissflogii (CCMP1336), and Dunaliella tertiolecta (CCMP1320). The MPN values were plotted against the ingestion rates (Fig. 1), and the $y$-intercepts represent the 'background' bacterial abundance of the copepods in the absence of food. The copepods had different 'background' MPNs among different experiments, suggesting that different batches of copepods might carry different amounts of bacteria due to differences in their physiological conditions and feeding history. Nevertheless, between the $R$. salina and $D$. tertiolecta experiments, there was a recurring trend that the bacterial abundance initially increased with the copepod's ingestion rate then appeared to level off at higher ingestion rates (Fig. 1). For the $T$. weissflogii treatment, the bacterial abundance appeared to decrease after the initial increase (Fig. 1). In order to compare the different experiments, the MPN values of each experiment were normalized to the average 'background' MPN of that experiment, and the normalized MPNs were plotted against the measured ingestion rates (Fig. 2). For the R. salina and
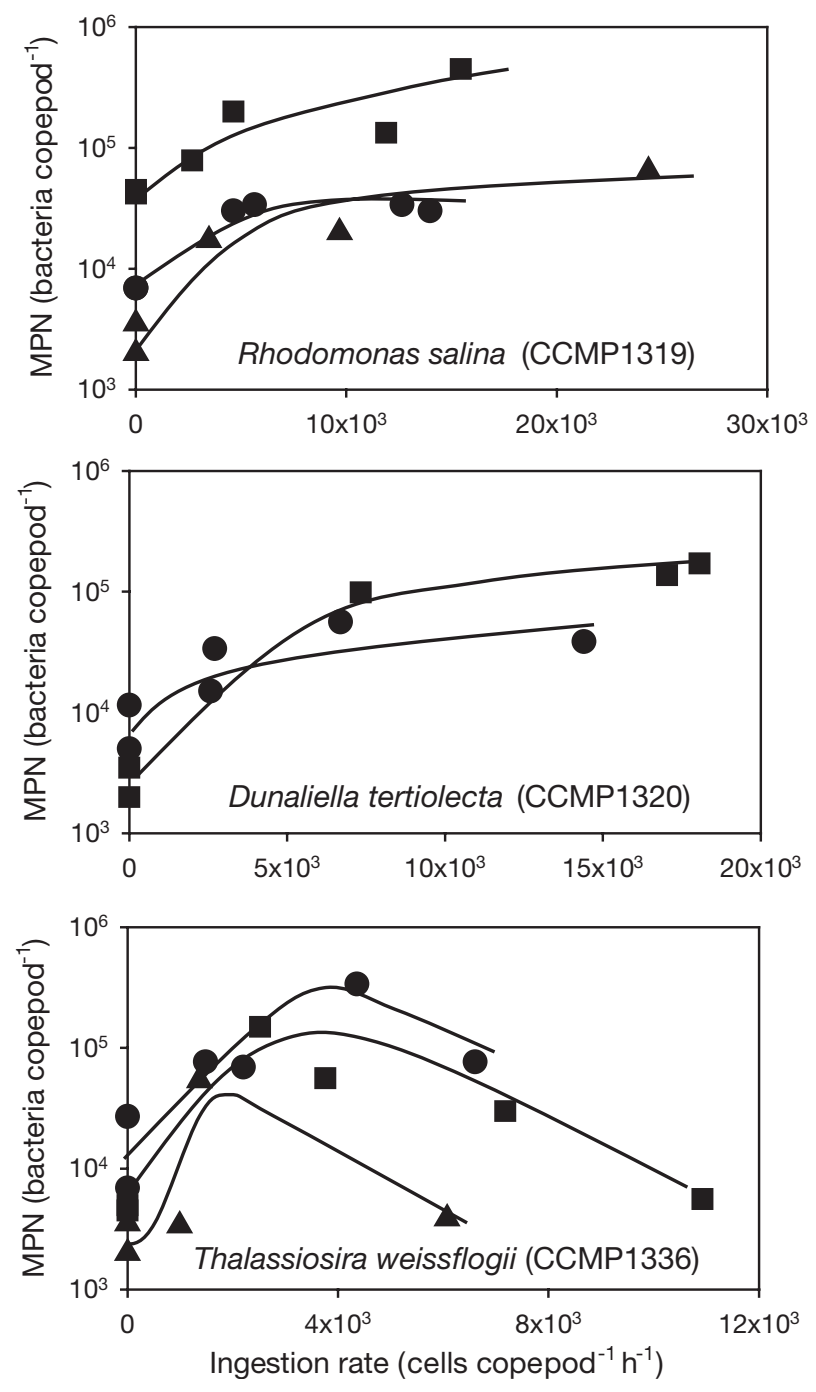

Fig. 1. Bacterial abundance associated with Acartia tonsa as a function of the copepod's ingestion rate on different axenic cultures of algal species. Each data point represents the ingestion rate and the corresponding Most Probable Number (MPN) of 1 incubation bottle. Symbols represent different experimental trials. Trend lines are drawn by hand

D. tertiolecta experiments, the normalized MPNs increased with the host copepod's ingestion rates ( $p<$ $0.05)$, with a linear regression function explaining 66 to $69 \%$ of the variations in the observations (Fig. 2). At the highest ingestion rates observed, the MPNs of the copepods increased by about 20 and 60 times relative to the 'background' MPNs when feeding on $R$. salina and $D$. tertiolecta, respectively. For the T. weissflogii experiments, the normalized MPN increased by about 30 times from the 'background' MPN at an ingestion rate of about $3 \times 10^{3}$ cells copepod ${ }^{-1} \mathrm{~h}^{-1}$, but quickly decreased to near the 'background' MPN as ingestion rate continued to increase (Fig. 2). 

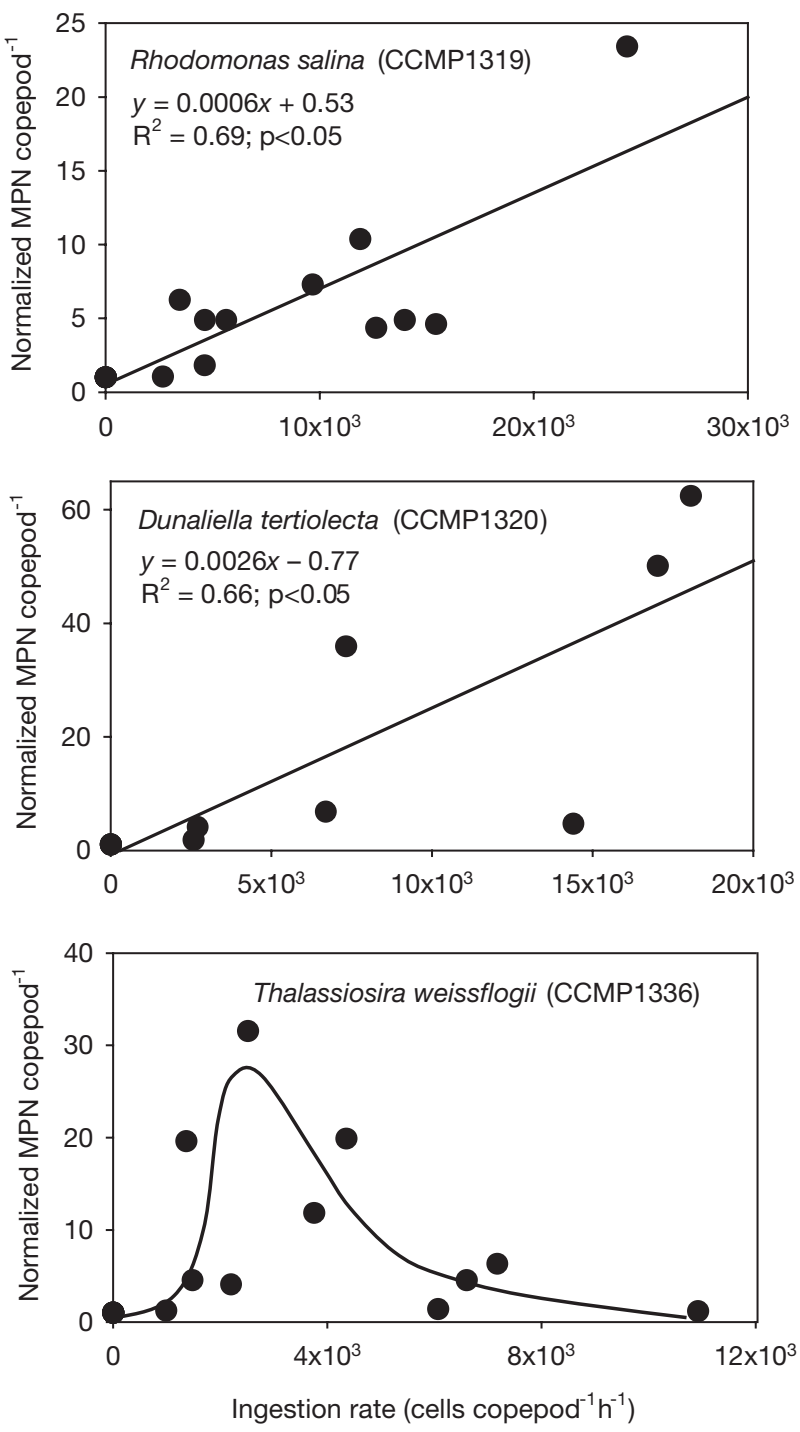

Fig. 2. Normalized bacterial abundance associated with Acartia tonsa as a function of the copepod's ingestion of different axenic cultures of algal species. Results are compiled from all feeding experiments for each algal species. Each data point represents the ingestion rate and the corresponding normalized Most Probable Number (MPN) of 1 incubation bottle. For Rhodomonas salina and Dunaliella tertiolecta, data are fitted to a linear regression functions. For Thalassiosira weissflogii, trend line is drawn by hand

\section{Time series experiment}

The copepods contained about $10^{4}$ bacteria ind. ${ }^{-1}$ prior to feeding. After $1 \mathrm{~d}$ of feeding the bacterial abundance decreased slightly but not significantly (1-way ANOVA followed by Tukey's HSD test; $\mathrm{p}>$ 0.05; Fig. 3). By the end of $3 \mathrm{~d}$ of feeding the bacteria abundance of the copepods increased significantly to near $10^{5} \operatorname{copepod}^{-1}$ ( $\mathrm{p}<0.05$; Fig. 3).

\section{Defecation experiment}

Among the 3 control bottles only 1 contained bacteria at the end of the experiment; however, the MPN value was very low (200 bacteria recovered from a volume of $129 \mathrm{ml}$ ), possibly a result of accidental contamination during sample processing. From the bottles with starved copepods slightly more bacteria were recovered (averaged 2200 bacteria per bottle; Fig. 4), but the MPN value was not significantly different from that of the control (1-way ANOVA followed by Tukey test; $p>0.05$; Fig. 4). In contrast, the amounts of bacteria recovered from the bottles with fed copepods were significantly higher than the other treatments, at $9.2 \times$ $10^{4}$ bacteria bottle ${ }^{-1}$ ( $p<0.05$; Fig. 4). Fecal pellet production rate averaged 140 pellets copepod ${ }^{-1} \mathrm{~d}^{-1}$. To correct for bacteria introduced by contamination, the

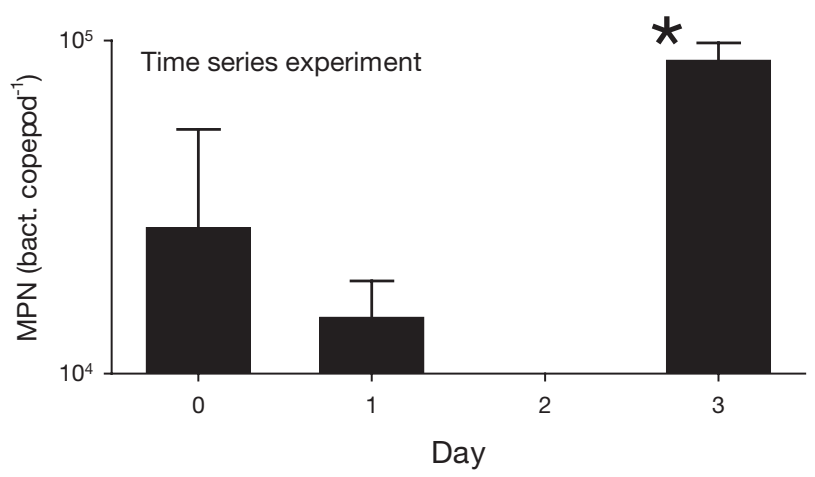

Fig. 3. Change in bacterial abundance associated with Acartia tonsa fed axenic cultures of Thalassiosira weissflogii. Error bar represents $1 \mathrm{SD}$ of triplicate. Bacterial abundance was significantly higher on Day 3 (1-way ANOVA followed by Tukey's HSD test; $*: p<0.05)$. MPN: Most Probable Number

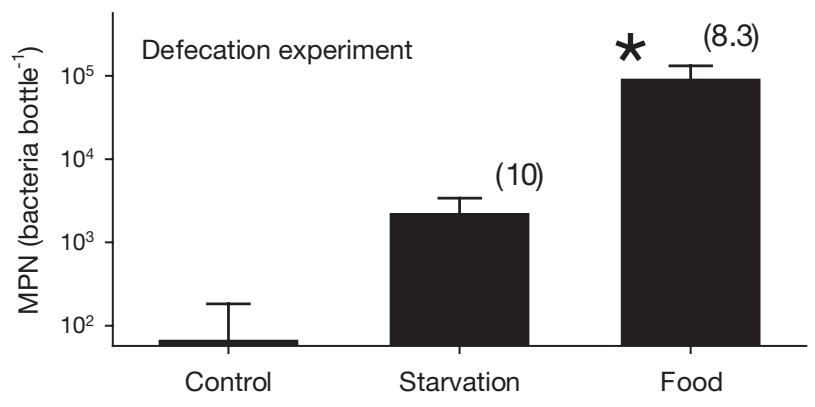

Fig. 4. Amount of particle-bound bacteria recovered from the defecation experiment. Control bottles contained only axenic cultures of Thalassiosira weissflogii; starvation treatment contained Acartia tonsa without food; food treatment contained A. tonsa feeding on axenic cultures of $T$. weissflogii. Numbers in parentheses represent average number of copepods per bottle. Error bar represents 1 SD of triplicate. Recovered bacterial abundance was significantly higher in food treatment (1-way ANOVA followed by Tukey's HSD test; $*$ : $\mathrm{p}<0.05$ ). MPN: Most Probable Number 
MPN value for the control was subtracted from the starvation treatment and the food treatment. The corrected MPN values were than normalized to the number of copepods in the bottles and extrapolated to the number of bacteria released copepod $\mathrm{d}^{-1} \mathrm{~d}^{-1}$. The results are shown in Fig. 4: Fed copepods on average would release $4.3 \times 10^{4}$ bacteria $\mathrm{d}^{-1}$ through defecation, significantly higher than the release by starved copepods of less than $10^{3}$ bacteria $\mathrm{d}^{-1}$ ( $t$-test; $\mathrm{p}<0.05$; Fig. 5).

\section{Bacterial growth experiment}

Enrichment cultures established with bacteria recovered from the 3 food treatments showed different

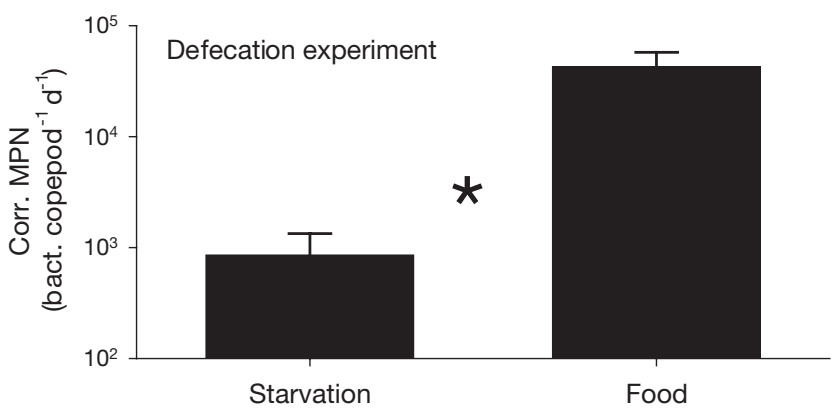

Fig. 5. Amount of bacteria released by Acartia tonsa $\mathrm{d}^{-1}$ in the absence or presence of food. Calculations are based on results from the defecation experiments (Fig. 4) using corrected (Corr.) bacteria abundances. Error bar represents 1 SD of triplicate. The estimated release of bacteria was significantly higher in the food treatment $(t$-test; $\mathrm{p}<0.05)$. MPN: Most Probable Number. $*: \mathrm{p}<0.05$

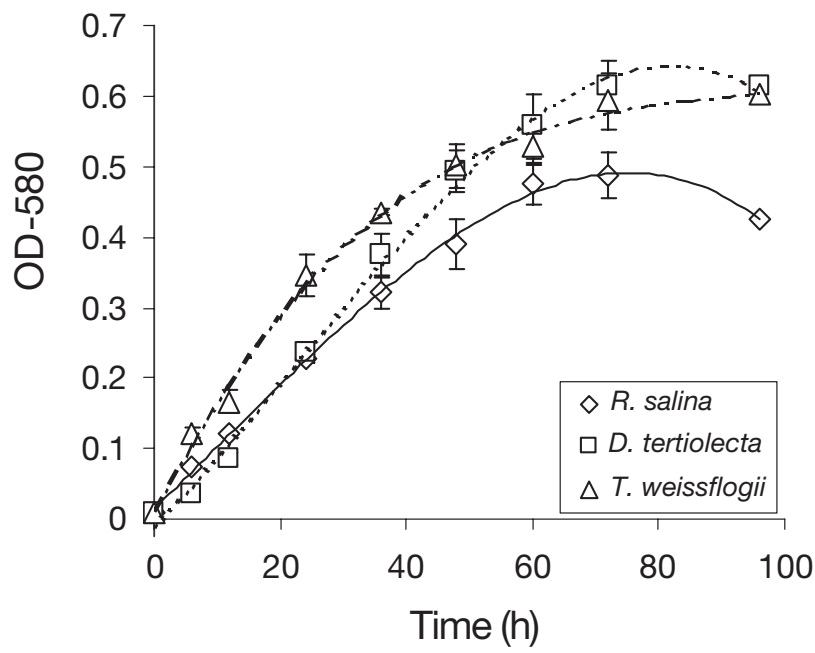

Fig. 6. Growth of enrichment cultures from different food treatments (Rhodomonas salina, Dunaliella tertiolecta, and Thalassiosira weissflogii) assessed as change in optical density $(\mathrm{OD})$ at $580 \mathrm{~nm}(\mathrm{OD}-580)$. Data are mean \pm SD of triplicates growth kinetics (Fig. 6). Within the first $20 \mathrm{~h}$, OD for the Thalassiosira weissflogii treatment increased faster than that for the Rhodomona salina treatment, which in turn increased slightly faster than that for the Dunaliella tertiolecta treatment. The OD of the $R$. salina treatment reached a plateau after $72 \mathrm{~h}$ and then declined toward the end of the experiment. The OD for the $T$. weissflogii treatment continued to increase but at a slower pace and approached a plateau after $96 \mathrm{~h}$. The OD for the D. tertiolecta treatment increased steadily and surpassed the other 2 treatments after 60 h; it increased until a plateau after 85 h, after which it declined. Despite the difference in growth kinetics, all DAPI-stained cells appeared to be small, thick rods under an epifluorescence microscope with no discernible differences in cell morphology.

\section{DISCUSSION}

Bacterial colonization of copepod bodies and fecal pellets has been reported by many investigators. Some investigators studied the bacteria using electronic microscopy (e.g. Nagasawa et al. 1985) or fluorescent stains (e.g. Hansen \& Bech 1996), yet these techniques do not differentiate between active and inactive bacteria. In the present study, a broad spectrum of organic substrates was employed to quantify live and active bacteria associated with copepod bodies and fecal pellets using the MPN method. Because only axenic cultures of phytoplankton were used as food in the experiments, the results reflect the dynamics of bacteria originated from the copepod bodies. In the feeding experiments, the 'background' MPN was fairly consistent, on the order of $10^{3}$ to $10^{4}$ bacteria copepod $^{-1}$ among all experiments. The 'background' MPN was higher than $10^{4}$ bacteria copepod ${ }^{-1}$ in only 2 of the experiments. These 'background' values were comparable to those reported by Hansen \& Bech (1996) based on colony-forming units on agar $\left(9 \times 10^{3}\right.$ bacteria copepod $^{-1}$ ).

The present study did not differentiate between bacteria on the copepod's exterior and bacteria inside a copepod's guts (cf. Hansen \& Bech 1996). Carman (1994) showed that the activity of bacteria (leucine incoroporation) attached to the copepod body surfaces could be stimulated by the host's excretion. As such, one may expect that higher excretion as a result of higher ingestion would lead to an increase in bacterial abundance on the copepod body surfaces. However, there is no a priori reason to expect a decline in the abundance of external bacteria as ingestion continues to increase. On the other hand, because bacteria inside a copepod's guts would rely on the host to supply organic substrates through ingestion, it might be 
expected that bacterial growth is a function of the host's ingestion rate. As ingestion rate continues to increase, defecation by the host copepod will also increase, which may flush out gut bacteria from the copepods' bodies. Thus, depending on whether bacterial loss due to defecation equals or exceeds bacterial growth as stimulated by ingestion, one would expect the MPN to approach a plateau or decrease at very high ingestion rates.

This conceptual model is consistent with the experimental results. Among the 3 food treatments, the MPN initially increased with ingestion rates, then either began to level off (Rhodomona salina and Dunaliella tertiolecta), or decreased at the higher ingestion rates (Thalassiosira weissflogii). Relative to the $R$. salina and $D$. tertiolecta treatments, the MPN in the T. weissflogii treatment reached a maximum at a lower ingestion rate before the decline. This is consistent with the fact that $T$. weissflogii contained more indigestible material than $R$. salina and D. tertiolecta, most notably the silicate frustules. Feeding studies have shown that copepods feeding on $T$. weissflogii have a higher defecation rate and produce bigger, more rigid fecal pellets (Feinberg \& Dam 1998, Besiktepe \& Dam 2002). Thus, when the copepod fed on T. weissflogii at high rates, the loss of bacteria from the gut via defecation might have exceeded their growth inside the copepod's guts. Another possible cause for the decline is a shift in the bacterial community to one dominated by strict anaerobes, which were less likely to be quantified by the present MPN method. Appearance of strict anaerobes in zooplankton guts and fecal pellets has been reported by several investigators (Bianchi et al. 1992, Proctor 1997). However, this explanation does not likely apply to the present results because it is not known that the oxic condition of copepod guts changes with ingestion rate, and because in the $R$. salina and $D$. tertiolecta treatments, the normalized MPN did not decline at high ingestion rates (Fig. 2). Among all the feeding experiments, the MPN ranged from $2 \times 10^{3}$ to $4.5 \times 10^{5}$ copepod $^{-1}$. Given a body volume of approximately $2.5 \times 10^{-5} \mathrm{ml}$ for Acartia tonsa, the equivalent bacterial population densities associated with the copepod would be $8 \times 10^{7}$ to $1.8 \times 10^{10}$ bacteria $\mathrm{ml}^{-1}$. These densities are much higher than the population densities of free-living bacteria, which are usually in the range of $10^{5}$ to $10^{6}$ bacteria $\mathrm{ml}^{-1}$.

In the time series experiment, the MPNs were not significantly different between starved copepods (Day 0) and copepods that had been feeding for $1 \mathrm{~d}$, suggesting that the bacteria required more than $1 \mathrm{~d}$ to respond to the host's feeding activities. However, between Day 1 and Day 3, the number of bacteria per copepod increased by nearly an order of magnitude. Since the copepods were feeding on an axenic culture of diatoms, an increase in bacterial abundance would have been a result of bacterial growth inside the copepod bodies fueled by organic matter ingested by the host copepod. The bacterial growth rate $\left(r ; \mathrm{d}^{-1}\right)$ between Day 1 and Day 3 could be then estimated as:

$$
r=\frac{\ln N_{t}-\ln N_{0}}{t}
$$

where $N_{t}=$ final bacteria copepod ${ }^{-1} ; N_{0}=$ initial bacteria $\operatorname{copepod}^{-1}$; $t=$ duration (d). The estimated bacterial growth rate was $0.89 \mathrm{~d}^{-1}$. This is a conservative estimate because it ignores the loss of bacteria via defecation (see 'Defecation experiment'). In comparison, the growth rate of water column bacteria averages 0.05 to $0.3 \mathrm{~d}^{-1}$ in the global ocean (Ducklow 1999). Thus, a copepod body could support not only a higher density of bacteria but also a higher bacterial growth rate than the water column.

Similar to copepods, non-living macroscopic particles such as marine snow also function as microbial hotspots to support high bacterial growth (Alldredge et al. 1986, Grossart et al. 2003). However, copepods are unique in 2 respects. While a non-living particle contains a finite amount of organic substrates, a copepod through feeding can continuously supply the bacteria with organic substrates. Also, a non-living particle does not have any active mechanism to remove the attached bacteria, and the loss of bacteria is usually a result of active emigration or predation by bacterivorous protozoans (Kiørboe et al. 2002, 2003). In the case of bacteria inside a copepod's guts, a major loss mechanism would be defecation by the host. Feeding and defecation of a copepod are usually tightly coupled such that the defecation rate increases with ingestion rate (e.g. Besiktepe \& Dam 2002). Past studies have shown that copepod's fecal pellets contain dense bacteria (Gowing \& Silver 1983, Jacobsen \& Azam 1984, Nagasawa \& Nemoto 1988, Hansen et al. 1996, Tang et al. 2001, Thor et al. 2003); however, because some of the former studies used non-axenic food, it could not be determined if the bacteria originated from the ingested food, or from inside the copepod's guts. In this study, the copepods were fed an axenic culture of diatoms; thus, bacteria recovered from the fecal pellets represented bacteria originating from the copepod's guts. An interesting observation is that a modest amount of bacteria were recovered even in the absence of food (Fig. 4), which might have been released directly from the copepod's guts, or cast off with broken body parts of the copepods. When food was present, defecation was evident by the appearance of numerous fecal pellets, and the amount of recovered bacteria increased by 40 times. By supporting bacteria growth via ingestion and sub- 
sequent release of bacteria via defecation, a copepod may be viewed as a source of bacteria to the water column.

How important is this mechanism for bacterial population dynamics in the water column? Using the results from the defecation experiment, it was estimated that a feeding copepod would release about $4.3 \times 10^{4}$ bacteria $\mathrm{d}^{-1}$. Based on an average population density of $1 \mathrm{l}^{-1}$ for Acartia tonsa in the spring in Long Island Sound, New York, when food availability is high (Tang et al. $2000)$, A. tonsa potentially release $4.3 \times 10^{4}$ bacteria $\mathrm{l}^{-1}$ daily, equivalent to $<0.1 \%$ of the standing stock of water column bacteria (assuming $10^{5} \mathrm{ml}^{-1}$ of water column bacteria). The actual amount of bacteria released by a zooplankter would depend on its feeding and defecation rates, which in turn are functions of food concentration, food type and temperature (Dam \& Peterson 1988, Butler \& Dam 1994, Besiktepe \& Dam 2002). In addition, natural food particles already carry attached bacteria (Kogure et al. 1981, Worm et al. 2001). Zooplankters feeding on these particles would bring external bacteria into their gut environment (Lawrence et al. 1993), where they may exploit the high concentration of organic substrates to attain increased growth. For example, in the present defecation experiment the fecal pellets contained on average 300 bacteria per pellet. In contrast, Thor et al. (2003) fed $A$. tonsa with a non-axenic culture of Thalassiosira weissflogii for $6 \mathrm{~h}$ and recovered over $3 \times 10^{4}$ bacteria per fecal pellet. Thus, bacterial output by copepods feeding on non-axenic food in nature could be a significant contribution of bacteria to the water column.

The volume of a typical fecal pellet could be estimated, based on the characteristic dimensions provided by Feinberg \& Dam (1998), to be $4.7 \times 10^{-7} \mathrm{ml}$. Thus, the equivalent bacterial abundance of a fecal pellet in the present study would be $6.5 \times 10^{8}$ bacteria $\mathrm{ml}^{-1}$, lower than the other studies (Lawrence et al. 1993, Tang et al. 2001). However, Lawrence et al. (1993) cautioned that their microscopic method did not differentiate between viable and non-viable bacteria associated with the fecal pellets. Tang et al. (2001) used the specific substrate dimethylsulfoniopropionate (DMSP) to quantify DMSP-consuming bacteria, so their results may not be comparable to the present results where the bacteria were grown in different substrates. Nevertheless, the MPN of bacteria recovered from fecal pellets in this study is $10^{2}$ to $10^{3}$ times higher than the average abundance of free bacteria in the water column. These bacteria not only may play a significant role in degrading the fecal pellets (Gowing \& Silver 1983, Jacobsen \& Azam 1984, Thor et al. 2003), but may also present a food source for bacterivorous protozoans in the water column. Many bacterivorous protozoans are capable of locating and colonizing microscale food patches (Caron et al. 1982, Fenchel \& Blackburn 1999, Kiørboe et al. 2003, 2004). Fecal pellets carrying dense bacteria may therefore attract the protozoans, and the significance of this source of bacteria in sustaining protozoan production in the ocean remains to be explored. Intense ectoenzyme activity by bacteria on fecal pellets could release significant amount of organic carbon from the fecal pellets, which would become available for even free-living bacteria (Thor et al. 2003).

By feeding on different food the copepods may introduce different types of organic substrates into their guts and fecal pellets to favor the growth of different bacteria. Tang et al. (2001) isolated DMSP-consuming bacteria (DCB) from Acartia tonsa. Because the metabolism of DMSP involves a specific group of bacteria (Visscher et al. 1992, Ledyard et al. 1993, Taylor \& Visscher 1996), DCB residing inside copepod's guts and fecal pellets would benefit only if the host has access to DMSP-containing food. In the bacterial growth experiments, bacteria recovered from different diet treatment showed different growth kinetics, suggesting that diet type for the host copepods may act as a selective force to favor different types of bacteria within the microhabitats. The copepod A. tonsa is omnivorous and can switch its diet among different food items. It grazes heavily on phytoplankton during spring blooms, but relies more on other food sources, particularly microzooplankton, during other times (Dam et al. 1994). This temporal shift in its diet may induce corresponding change in its residential bacterial community.

The traditional view of the marine food web depicts bacteria and zooplankton as 2 separate entities, indirectly connected via nutrient recycling and trophic cascade processes (e.g. Azam 1998). Yet, this and other studies clearly demonstrated that zooplankton and bacteria are directly connected, both physically (e.g. bacteria attaching to zooplankton bodies and fecal pellets) and biologically (e.g. zooplankton feeding supports bacterial growth, and defecation releases bacteria into the water column). Although zooplankton microhabitats may account for a minor fraction of the total bacterial biomass in the ocean, they represent extremely dense local populations of bacteria associated with highly concentrated sources of organic substrates. Thus, in terms of bacterial processes, these microhabitats may be far more active and dynamic than the bulk water column.

Acknowledgements. This study was made possible by a research grant from the Jeffress Memorial Trust (award number J-697) and funding from the Virginia Institute of Marine Science. Ms. J. Peloquin (VIMS) and Ms. M. Taal (Hampton University) provided technical assistance. Contribution no. 2626 of the Virginia Institute of Marine Science. 


\section{LITERATURE CITED}

Alldredge AL, Silver MW (1988) Characteristics, dynamics and significance of marine snow. Prog Oceanogr 20:41-82

Alldredge AL, Cole JJ, Caron DA (1986) Production of heterotrophic bacteria inhabiting macroscopic organic aggregates (marine snow) from surface waters. Limnol Oceanogr 31:68-78

Azam F (1998) Microbial control of oceanic carbon flux: the plot thickens. Science 280:694-696

Besiktepe S, Dam HG (2002) Coupling of ingestion and defecation as a function of diet in the calanoid copepod Acartia tonsa. Mar Ecol Prog Ser 229:151-164

Bianchi M, Marty D, Teyssié JL, Fowler SW (1992) Strictly aerobic and anaerobic bacteria associated with sinking particulate matter and zooplankton fecal pellets. Mar Ecol Prog Ser 88:55-60

Butler M, Dam HG (1994) Production rates and characteristics of fecal pellets of the copepod Acartia tonsa under simulated phytoplankton bloom conditions: implications for vertical fluxes. Mar Ecol Prog Ser 114:81-91

Carman KR (1994) Stimulation of marine free-living and epibiotic bacterial activity by copepod excretions. FEMS Microbiol Ecol 14:255-262

Carman KR, Dobbs FC (1997) Epibiotic microorganisms, ion copepods and other marine crustaceans. Microsc Res Tech 37:116-135

Caron DA, Davis PG, Madin LP, Sieburth JMcN (1982) Heterotrophic bacteria and bacterivorous Protozoa in oceanic macroaggregates. Science 218:795-797

Church MJ, Hutchins DA, Ducklow HW (2000) Limitation of bacterial growth by dissolved organic matter and iron in the Southern Ocean. Appl Environ Microbiol 66:455-466

Dam HG, Peterson WT (1988) The effect of temperature on the gut clearance rate constant of planktonic copepods. J Exp Mar Biol Ecol 123:1-14

Dam HG, Peterson WT, Bellantoni DC (1994) Seasonal feeding and fecundity of the calanoid copepod Acartia tonsa in Long Island Sound: is omnivory important to egg production? Hydrobiologia 292/3:191-199

Delille D, Razouls S (1994) Community structures of heterotrophic bacteria of copepod fecal pellets. J Plankton Res 16:603-615

DeMan JC (1975) The probability of most probable numbers. Eur J Appl Microbiol 1:67-78

Ducklow HW (1999) The bacteria component of the oceanic euphotic zone. FEMS Microbiol Ecol 30:1-10

Feinberg LR, Dam HG (1998) Effects of diet on dimensions, density and sinking rates of fecal pellets of the copepod Acartia tonsa. Mar Ecol Prog Ser 175:87-96

Fenchel T, Blackburn N (1999) Motile chemosensory behaviour of phagotrophic protists: mechanisms for and efficiency in congregating at food patches. Protist 150:325-336

Gowing MM, Silver MW (1983) Origins and microenvironments of bacteria mediating fecal pellet decomposition in the sea. Mar Biol 73:7-16

Grossart HP, Hietanen S, Ploug H (2003) Microbial dynamics on diatom aggregates in Øresund, Denmark. Mar Ecol Prog Ser 249:69-78

Hansen B, Bech G (1996) Bacteria associated with a marine planktonic copepod in culture. I. Bacterial genera in seawater, body surface, intestines and fecal pellets and succession during fecal pellet degradation. J Plankton Res 18: 257-273

Hansen B, Fotel FL, Jensen NJ, Madsen SD (1996) Bacteria associated with a marine planktonic copepod in culture. II. Degradation of fecal pellets produced on a diatom, a nanoflagellate or a dinoflagellate diet. J Plankton Res 18: $275-288$

Hines ME, Visscher PT, Devereux R (1997) Sulfur cycling. In: Hurst CJ, Knudsen GR, McInerney MJ, Stetzenbach LD, Walter MV (eds) Manual of environmental microbiology. ASM Press, Washington, DC, p 324-334

Honjo S, Roman MR (1978) Marine copepod fecal pellets: production, preservation and sedimentation. J Mar Res 36: $45-57$

Jacobsen TR, Azam F (1984) Role of bacteria in copepod fecal pellet decomposition: colonization, growth rates and mineralization. Bull Mar Sci 35:495-502

Kiørboe T, Grossart H-P, Ploug H, Tang K (2002) Mechanisms and rates of bacterial colonization of sinking aggregates. Appl Environ Microbiol 68:3996-4006

Kiørboe T, Tang K, Grossart H-P, Ploug H (2003) Dynamics of microbial communities on marine snow aggregates: colonization, growth, detachment and grazing mortality of attached bacteria. Appl Environ Microbiol 69:3036-3047

Kiørboe T, Grossart H-P, Ploug H, Tang K, Auer B (2004) Particle associated flagellates: swimming patterns, colonization rates, and grazing on attached bacteria. Aquat Microb Ecol 35:141-152

Kirchman DL, Rich JH (1997) Regulation of bacterial growth rates by dissolved organic carbon and temperature in the Equatorial Pacific Ocean. Microb Ecol 33:11-20

Kogure K, Simidu U, Taga N (1981) Bacterial attachment to phytoplankton in sea water. J Exp Mar Biol Ecol 56: 197-204

Lawrence SG, Ahmad A, Azam F (1993) Fate of particlebound bacteria ingested by Calanus pacificus. Mar Ecol Prog Ser 97:299-307

Ledyard KM, DeLong EF, Dacey JWH (1993) Characterization of a DMSP-degrading bacterial isolate from the Sargasso Sea. Arch Microbiol 160:312-318

Nagasawa S, Nemoto T (1988) Presence of bacteria in guts of marine crustaceans and on their fecal pellets. J Plankton Res 10:559-564

Nagasawa S, Simidu U, Nemoto T (1985) Scanning electron microscopy investigation of bacterial colonization of the marine copepod Acartia clausi. Mar Biol 87:61-66

Ploug H, Grossart HP, Azam F, Jørgensen BB (1999) Photosynthesis, respiration, and carbon turnover in sinking marine snow from surface waters of Southern California Bight: implications for the carbon cycle in the ocean. Mar Ecol Prog Ser 179:1-11

Pomeroy LR, Wiebe WJ (2001) Temperature and substrates as interactive limiting factors for marine heterotrophic bacteria. Aquat Microb Ecol 23:187-204

Proctor LM (1997) Nitrogen-fixing, photosynthetic, anaerobic bacteria associated with pelagic copepods. Aquat Microb Ecol 12:105-113

Simon M, Grossart H-P, Schweitzer B, Ploug H (2002) Microbial ecology of organic aggregates in aquatic ecosystems. Aquat Microb Ecol 28:175-211

Smith DC, Simon M, Alldredge AL, Azam F (1992) Intense hydrolytic enzyme activity on marine aggregates and implications for rapid particle dissolution. Nature 359: 139-142

Tang KW, Rogers DR, Dam HG, Visscher PT (2000) Seasonal distribution of DMSP among seston, dissolved matter and zooplankton along a transect in the Long Island Sound estuary. Mar Ecol Prog Ser 206:1-11

Tang KW, Visscher PT, Dam HG (2001) DMSP-consuming bacteria associated with the calanoid copepod Acartia tonsa (Dana). J Exp Mar Biol Ecol 256:185-198

Taylor BF, Visscher PT (1996) Metabolic pathways involved in 
DMSP degradation. In: Kiene RP, Visscher PT, Keller MD, Kirst GO (eds) Biological and environmental chemistry of DMSP and related sulfonium compounds. Plenum Press, New York, p 265-276

Thor P, Dam HG, Rogers DR (2003) Fate of organic carbon released from decomposing copepod fecal pellets in relation to bacterial production and ectoenzyme activity. Aquat Microb Ecol 33:279-288

Turley CM, Mackie PJ (1994) Biogeochemical significance of attached and free-living bacteria and the flux of particles in the NE Atlantic Ocean. Mar Ecol Prog Ser 115:191-203 Turner JT (1979) Microbial attachment to copepod fecal pel-

Editorial responsibility: John Dolan, Villefrache-sur-Mer, France lets and its possible ecological significance. Trans Am Microsc Soc 98:131-135

Turner JT (2002) Zooplankton fecal pellets, marine snow and sinking phytoplankton blooms. Aquat Microb Ecol 27: 57-102

Visscher PT, Diaz MR, Taylor BF (1992) Enumeration of bacteria which cleave or demethylate dimethylsulfoniopropionate in the Caribbean Sea. Mar Ecol Prog Ser 89:293-296

Worm J, Gustavson K, Garde K, Borch NH, Soendergaard M (2001) Functional similarity of attached and free-living bacteria during freshwater phytoplankton blooms. Aquat Microb Ecol 25:103-111

Submitted: August 1, 2004; Accepted: October 6, 2004

Proofs received from author(s): December 21, 2004 